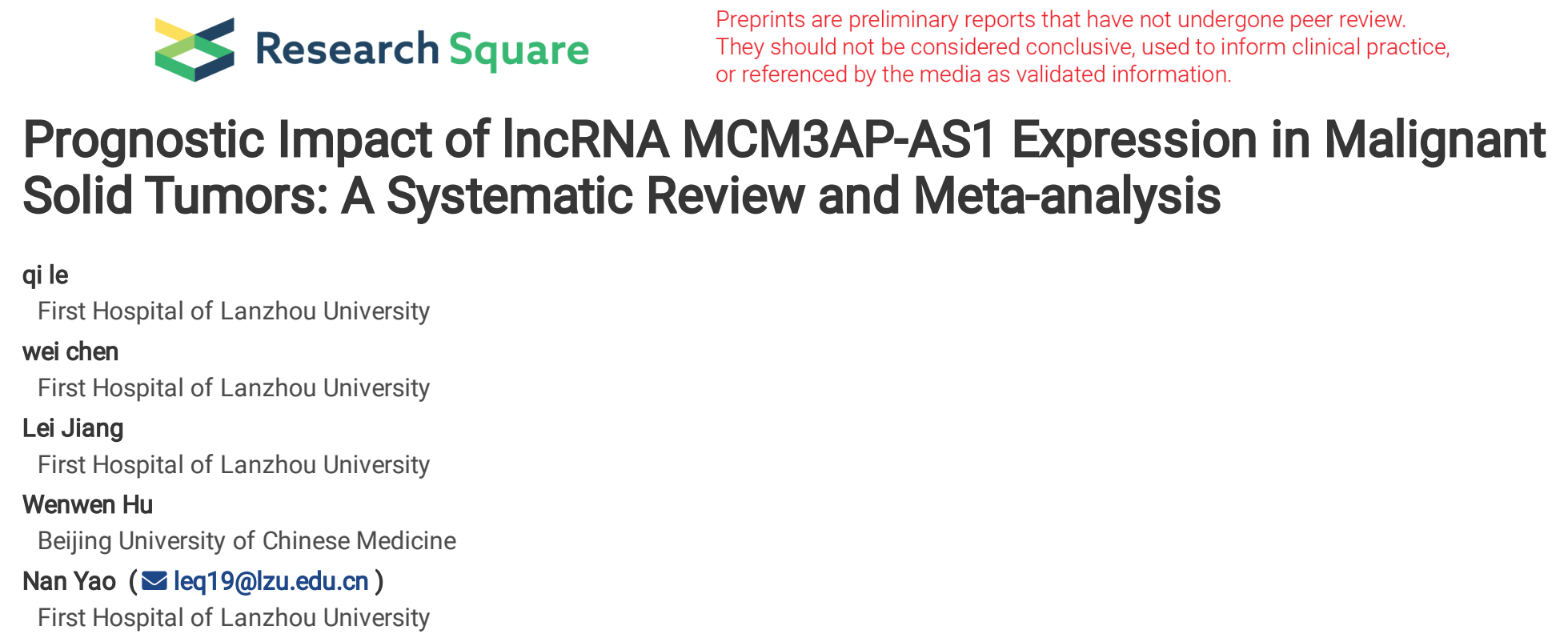

\section{Prognostic Impact of IncRNA MCM3AP-AS1 Expression in Malignant Solid Tumors: A Systematic Review and Meta-analysis}




\section{Abstract}

Objectives: MCM3AP-AS1 is a newly discovered long non-coding RNA that functions as a biomarker in many different cancer types. However, the pooled role of IncRNA MCM3AP-AS1 in the prognosis of human cancers remains unclear. We performed a systematic review and metaanalysis to explore its potential prognosis for malignant tumors.

Materials and methods: A literature survey was conducted by searching in the PubMed, Embase, Web of Science, China National Knowledge Infrastructure and Wanfang databases for studies published as of September 1, 2021. The pooled hazard ratio (HR) and $95 \%$ confidence interval $(95 \% \mathrm{Cl})$ were calculated to evaluate the relationship between MCM3AP-AS1 expression and overall survival (OS). The endpoints also included various clinical parameters.

Results: A total of 14 studies containing 921 cancer patients were finally included into this meta-analysis. The results comprehensively showed that increased MCM3AP-AS1 expression was significantly correlated with poor overall survival $(\mathrm{HR}=1.83,95 \% \mathrm{Cl}$ : 1.56-2.14, $\mathrm{P}<0.00001)$. A subgroup meta-analysis for overall survival was conducted. Additionally, high level of IncRNA MCM3AP-AS1 was significantly associated with worse differentiation ( $O R=1.76,95 \% \mathrm{Cl}: 1.12-2.75, \mathrm{P}=0.01)$, larger tumor size $(\mathrm{OR}=2.70,95 \% \mathrm{Cl}: 1.13-6.46, \mathrm{P}=0.03)$, advanced clinical stage $(\mathrm{OR}=2.52,95 \% \mathrm{Cl}: 1.32-4.81, \mathrm{P}=0.005)$ and lymph node metastasis $(\mathrm{OR}=2.85,95 \% \mathrm{Cl}: 1.16-7.00, \mathrm{P}=0.02)$, respectively.

Conclusions: LncRNA MCM3AP-AS1 might be a potential and unfavorable prognostic biomarker of cancer.

\section{Introduction}

As a major global public health problem, cancer was currently the third leading cause of death worldwide, significantly increasing the economic burden on society and families[1]. According to the latest statistics, the number of cancer patients increased by approximately 19.3 million in 2020, and the number of cancer-related deaths increased by about 10 million all over the world. It was clear that the global cancer incidence and mortality rates were increasing rapidly as the population grows and ages[2]. Despite significant breakthroughs in the diagnosis and treatment of cancer in recent years, the prognosis of cancer patients remained poor, and the 5-year survival rates for most malignancies were still unsatisfactory, especially for patients with advanced stages and distant metastasis. Apparently, early detection of cancer strongly reduced cancer mortality and extend life. Moreover, potential biomarkers might play a critical role in the early diagnosis, treatment and prediction of cancer[3]. Therefore, the issue of digging a potential novel tumor biomarker has become imminent for improving cancer treatment and predicting cancer prognosis.

Long non-coding RNA (LncRNA) was a kind of RNA transcripts of non-coding proteins that were more than 200 nucleotides in length[4]. It was well known that about $93 \%$ of DNA in the human genome was transcribed into RNA. However, only $2 \%$ of the RNA was coding for proteins, and the remaining $98 \%$ was called non-coding RNA $[5,6]$. In the past, due to the limitations of knowledge and technic, IncRNA was considered as dark-matter or noise of genomic transcription, a by-product of RNA polymerase II transcription[7]. For example, H19[8] and XIST [9], first discovered in the early 1990s, were both considered as transcriptional noise. In recent years, with the development and advancement of various RNA sequencing technologies and transcriptome analysis techniques, the localization and functions of IncRNAs have been gradually clarified. A large body of evidence suggested that LncRNAs were involved in regulating transcriptional programs, epigenetic modifications, mediating protein and RNA stability, translation and post-translational modifications, and a variety of other important cellular physiological processes[10,11]. LncRNAs were also involved in various biological processes related to tumors, such as anti-apoptosis, tumor cell proliferation, induction of angiogenesis, promotion of metastasis and evasion of tumor suppression[12]. Prensner JR et al. found that overexpression of prostate cancer-associated transcript 1 (PCAT-1) promoted tumor cell proliferation in vitro experiments[13]. Ji and Diederichs et al. showed that metastasis-associated lung adenocarcinoma transcript 1 (MALAT-1) was involved in regulating tumor cell behavior, such as invasion and metastasis, and could be used as a prognostic marker for non-small cell lung cancer (NSCLC) metastasis and survival time[14]. Evidently, IncRNAs have became important in the physiological activities of cells and the regulation of disease processes, especially cancers.

LncRNA Minichromosome maintenance complex component 3 associated protein-antisense RNA 1(LncRNA MCM3AP-AS1) was a noncoding antisense transcript derived from MCM3AP. MCM3AP (initially called Map80) composed with 721 amino acids and calculated molecular weight as 80,291, was located at the 21q22.3 region of the human chromosome[15]. MCM3AP worked as an acety/transferase, acetylating the replication protein MCM3 and participating in the regulation of the DNA replication process[16]. In recent years, a large amount of literature has reported that InCRNA MCM3AP-AS1 expression was upregulated in a variety of cancers and associated with poor prognosis, such as hepatocellular carcinoma[17], prostate cancer[18], non-small cell lung cancer[19], and colorectal cancer[20]. However, Dai et al. found that MCM3AP-AS1 expression was downregulated in colorectal cancer with predicting poor prognosis. MCM3AP-AS1 inhibited the progression of colorectal cancer by suppressing the molecular sponge of miR-19a-3p expression and subsequently positively 
regulated forkhead box F2 (FOXF2) expression[21]. There were still controversy results obtained from many studies. And most studies on the effects of MCM3AP expression have been limited by sample size and discrete results. Therefore, our study was performed by quantitative meta-analysis to assess the correlation between MCM3AP-AS1 expression and the clinicopathological characteristics or prognosis of different cancer types.

\section{Matericals And Methods}

\subsection{Literature search}

Publications on the relevance of IncRNA expression to tumor prognosis published up to September 1, 2021 were collected by searching online databases such as PubMed (National Library of Medicine, Bethesda, Maryland, USA), Web of Science (Clarivate Analytics, Philadelphia, Pennsylvania, USA), Embase (Elsevier, Amsterdam, The Netherlands), CNKI (China National Knowledge Infrastructure, CHINA) and Wanfang databases (CHINA). The search terms were shown as followings: "long non-coding RNA MCM3AP-AS1" OR "InCRNA MCM3APAS1" OR "MCM3AP-AS1" OR "MCM3AP antisense RNA 1" OR "minichromosome maintenance complex component 3 associated protein antisense RNA1" in combination with "tumor" OR "cancer" OR "neoplasm" OR "carcinoma". The references of included articles were also manually reviewed to avoid omission of relevant studies.

\subsection{Inclusion criteria and exclusion criteria}

The inclusion criteria were displayed as followings: (1) detecting the expression level of MCM3AP-AS1 in cancer tissues; (2) patients were divided into high and low expression groups according to the level of MCM3AP-AS1; (3) described the association between MCM3AP-AS1 expression and prognostic or clinicopathological features; (4) studies where hazard ratio (HR) and $95 \%$ confidence interval (95\% Cl) could be obtained directly or $\mathrm{HR}$ and $95 \% \mathrm{Cl}$ could be calculated indirectly from survival curves. The following papers were excluded from this study: (1) reviews, case reports, letters, editorials, meta-analyses and conference reports; (2) papers with unusable or insufficient data; (3) nonhuman studies; (4) duplicate publications.

\subsection{Data extraction and quality assessment}

Two researchers independently extracted information from the papers based on inclusion and exclusion criteria and cross-checked the results. In case of disagreements, they were resolved through discussion with a third reviewer. The following information was carefully extracted from the articles included in this study: the family name of first author, the year of publication, country, tumor type, total patient number, percent of high expression, detection method of IncRNA MCM3AP-AS1 expression, cut-off value, survival analysis methodology, prognostic parameters, follow up time and clinical parameters. Then, we extracted $\mathrm{HR}$ and $95 \% \mathrm{Cl}$ directly from the articles. When $\mathrm{HR}$ and $95 \% \mathrm{Cl}$ were not given directly in the papers, the $\mathrm{HR}$ and $95 \% \mathrm{Cl}$ were calculated from Kaplan-Meier survival curves by using Engauge Digitizer version 11.0. The clinical parameters included age, gender, differentiation grade, tumor size, lymph node metastasis (LNM), distant metastasis (DM) and clinical stage for each subgroup. Subsequently, the quality of the included literature was evaluated by the Newcastle-Ottawa scale (NOS). The evaluation included study population, comparability between groups, and outcome indicators. NOS scores ranged from 0 to 9 , and a study was considered high quality if the score was $\geq 6$.

\subsection{Statistiacal analysis}

All statistical analysis was performed by Review Manager version 5.4 (Revman, The Cochrane Collaboration, Oxford, UK) and Stata 12.0 software (StataCorp, College Station, TX, USA). Hazard ratio and its corresponding 95\% confidence interval were utilized to evaluate the association of MCM3AP-AS1 with clinical prognosis, and the assessment index was OS. The odds ratio (OR) was applied to assess the strength of the association between MCM3AP-AS1 expression level with clinicopathological parameters, including age, gender, tumor size, clinical stage, differentiation grade, distant metastasis and lymph node metastasis. $X^{2}$-based Cochran $Q$ test and Higgins $P$ statistic were used to determine the heterogeneity among the included studies. $I^{2}$ values $>50 \%$ or $P$-values $<0.05$ indicated obvious heterogeneity among the included studies and the random-effects model was applied for the analysis. Otherwise, the fixed-effects model was used. Subgroup and sensitivity analyses were performed to analyze the sources of heterogeneity. Additionally, potential publication bias of the included literature was detected by Begg's funnel plot and Egger's test. If $\mathrm{P}<0.05$ indicates obvious publication bias.

\section{Results}

Page $3 / 14$ 


\subsection{Literature selected procedure}

As is exhibited in Fig.1, we retrieved the related papers in PubMed, Embase, Web of Science, China National Knowledge Infrastructure, and Wanfang database. A total of 120 papers were initially acquired. Then, we deleted 76 duplicate publications among them. Subsequently, 19 papers were eliminated by browsing titles and abstracts of the remaining studies. Next, we attentively reviewed the full-text of 25 papers and excluded the 11 papers with inadequate data for analysis. Finally, 14 eligible studies containing 935 patients were met the inclusion criteria and used to perform this meta-analysis and systemic review.

\subsection{Detailed characteristics of included studies}

The basic information of 14 eligible studies were presented in Table 1. All eligible papers were performed by Chinese researchers. Among those studies, 12 tumor types were evaluated, including non-small-cell lung cancer, endometrioid carcinoma, colorectal cancer, oral squamous cell carcinoma, cervical squamous cell carcinoma, prostate cancer, Burkitt lymphoma, clear cell renal cell carcinoma, nasopharyngeal carcinoma, pancreatic cancer, papillary thyroid cancer, hepatocellular carcinoma. The sample sizes differed from 41 to 131.

The high expression of MCM3P-AS1 among those studies ranged from 38.5\% to 68\%. The level of MCM3P-AS1 were detected by quantitative reverse transcription polymerase chain reaction (qRT-PCR) in all studies. The cut-off value was reported in various methods, including mean ( 1 study), median (11 studies), fold change (1 study), and not reported (1 study). The survival analysis was descripted by multivariate analysis (6 studies) or survival curve (5 studies), while 3 studies were displayed without survival analysis. With respect to cancer outcomes, 7 studies were mentioned with both OS and CP, while others only reported with OS or CP. The follow-ups were varied from $33.3 \mathrm{months}$ to 160 months in studies with OS. Moreover, the NOS score was more than 6 in all studies.

Table 1

Main characteristics of all included studies. 


\begin{tabular}{|c|c|c|c|c|c|c|c|c|c|c|c|}
\hline Study & Country & Tumor type & Sample & $\begin{array}{l}\text { Total } \\
\text { cases }\end{array}$ & $\begin{array}{l}\text { Percent } \\
\text { of } \\
\text { positive }\end{array}$ & $\begin{array}{l}\text { Detection } \\
\text { method }\end{array}$ & $\begin{array}{l}\text { Cut-off } \\
\text { value }\end{array}$ & $\begin{array}{l}\text { Survival } \\
\text { analysis }\end{array}$ & Outcomes & $\begin{array}{l}\text { Follow } \\
\text { up } \\
\text { (mo) }\end{array}$ & NOS \\
\hline $\begin{array}{l}\text { Shen, } \\
2021\end{array}$ & China & $\begin{array}{l}\text { non-small-cell } \\
\text { lung cancer }\end{array}$ & tissue & 63 & $50.8 \%$ & qRT-PCR & median & NR & $\mathrm{CP}$ & NR & 6 \\
\hline $\begin{array}{l}\text { Yu, } \\
2021\end{array}$ & China & $\begin{array}{l}\text { endometrioid } \\
\text { carcinoma }\end{array}$ & tissue & 60 & $50.0 \%$ & qRT-PCR & median & MA & $\mathrm{OS}, \mathrm{CP}$ & 60 & 8 \\
\hline $\begin{array}{l}\text { Zhou, } \\
2021\end{array}$ & China & $\begin{array}{l}\text { colorectal } \\
\text { cancer }\end{array}$ & tissue & 131 & $68.0 \%$ & qRT-PCR & NR & SC & OS & 160 & 7 \\
\hline $\begin{array}{l}\text { Dai, } \\
2021\end{array}$ & China & $\begin{array}{l}\text { colorectal } \\
\text { cancer }\end{array}$ & tissue & 53 & $49.1 \%$ & qRT-PCR & median & NR & $\mathrm{CP}$ & NR & 6 \\
\hline $\begin{array}{l}\text { Hou, } \\
2020\end{array}$ & China & $\begin{array}{l}\text { oral squamous } \\
\text { cell carcinoma }\end{array}$ & tissue & 36 & $47.2 \%$ & qRT-PCR & median & NR & $\mathrm{CP}$ & NR & 6 \\
\hline $\begin{array}{l}\text { Liu, } \\
2020\end{array}$ & China & $\begin{array}{l}\text { cervical } \\
\text { squamous cell } \\
\text { carcinoma }\end{array}$ & tissue & 64 & $50.0 \%$ & qRT-PCR & median & MA & os & 60 & 8 \\
\hline $\begin{array}{l}\text { Jia, } \\
2020\end{array}$ & China & prostate cancer & tissue & 64 & $42.2 \%$ & qRT-PCR & mean & MA & $\mathrm{OS}, \mathrm{CP}$ & 60 & 8 \\
\hline $\begin{array}{l}\text { Ma, } \\
2020\end{array}$ & China & $\begin{array}{l}\text { colorectal } \\
\text { cancer }\end{array}$ & tissue & 60 & $50.0 \%$ & qRT-PCR & median & MA & OS,CP & 60 & 8 \\
\hline $\begin{array}{l}\text { Guo, } \\
2020\end{array}$ & China & $\begin{array}{l}\text { burkitt } \\
\text { lymphoma }\end{array}$ & tissue & 41 & $39.0 \%$ & qRT-PCR & $\mathrm{FC}$ & SC & os & 60 & 7 \\
\hline $\begin{array}{l}\text { Qiu, } \\
2020\end{array}$ & China & $\begin{array}{l}\text { clear cell renal } \\
\text { cell carcinoma }\end{array}$ & tissue & 78 & $38.5 \%$ & qRT-PCR & median & MA & OS,CP & 60 & 8 \\
\hline $\begin{array}{l}\text { Sun, } \\
2020\end{array}$ & China & $\begin{array}{l}\text { nasopharyngeal } \\
\text { carcinoma }\end{array}$ & tissue & 55 & $51.0 \%$ & qRT-PCR & median & MA & OS,CP & 60 & 8 \\
\hline $\begin{array}{l}\text { Yang, } \\
2019\end{array}$ & China & $\begin{array}{l}\text { pancreatic } \\
\text { cancer }\end{array}$ & tissue & 86 & $50.0 \%$ & qRT-PCR & median & SC & OS,CP & 33.3 & 8 \\
\hline $\begin{array}{l}\text { Liang, } \\
2019\end{array}$ & China & $\begin{array}{l}\text { papillary thyroid } \\
\text { cancer }\end{array}$ & tissue & 64 & $50.0 \%$ & qRT-PCR & median & SC & OS & 60 & 8 \\
\hline $\begin{array}{l}\text { Wang, } \\
2019\end{array}$ & China & $\begin{array}{l}\text { hepatocellular } \\
\text { carcinoma }\end{array}$ & tissue & 80 & $50.0 \%$ & qRT-PCR & median & SC & OS,CP & 60 & 8 \\
\hline
\end{tabular}

\subsection{Association between MCM3P-AS1 and OS}

Eleven studies reported with OS and the HRs that extracted from those survival outcomes were used to perform this meta-analysis. As shown in Fig. $2 a$, the random-effect model was adopted due to the high heterogeneity $\left(I^{2}=56 \%, P=0.01\right)$, and the pooled $\mathrm{HR}$ was 1.66 (95\% Cl: 1.39-1.98, $\mathrm{P}<0.00001$ ). For unveiled the source of high heterogeneity, we performed the sensitivity analysis (Fig. 3 ). Then, we found that two studies influenced the results of pooled HR and contributed to high heterogeneity. We subsequently removed two studies and used fixedeffect model to assess the relationship between the expression of IncRNA MCM3P-AS1 and OS with low heterogeneity $\left(I^{2}=0 \% ; P=0.52\right)$. The pooled HR was 0.83 (95\% Cl: 1.56-2.14, P<0.00001) (Fig. 2b).

To further hierarchically explore the relationship between MCM3P-AS1 and OS based on various cancer types, survival analysis, and cut-off values, the subgroup analyses were applied. As shown in Table 2, the results suggested that the significant association between the increased expression of MCM3P-AS1 and poor OS in digestive system tumors ( $\mathrm{HR}=1.68,95 \% \mathrm{Cl}: 1.36-2.09, \mathrm{P}<0.00001)$, and other tumors $(H R=1.97,95 \% \mathrm{Cl}: 1.52-2.56, \mathrm{P}<0.00001)$. Then, we performed the subgroup analysis of survival analysis, and high level of MCM3P-

AS1 was obviously related to OS with both in survival curves ( $H R=1.63,95 \% \mathrm{Cl}: 1.28-2.07, \mathrm{P}<0.0001)$ and multivariate analysis $(H R=1.96$, $95 \% \mathrm{Cl}: 1.56-2.47, \mathrm{P}<0.00001)$. Moreover, in the subgroup of cut-off values, overexpression of IncRNA MCM3P-AS1 was strongly correlated to OS in studies adopting median ( $\mathrm{HR}=1.84,95 \% \mathrm{Cl}: 1.51-2.24, \mathrm{P}<0.00001)$ and others ( $\mathrm{HR}=1.68,95 \% \mathrm{Cl}: 1.23-2.29, \mathrm{P}=0.0001)$. 
Table 2

Subgroup analyses of pooled hazard ratios for overall survival.

\begin{tabular}{|c|c|c|c|c|c|c|c|}
\hline \multirow[t]{2}{*}{ Categories } & \multirow[t]{2}{*}{ Studies (n) } & \multirow[t]{2}{*}{ Number of patients } & \multirow[t]{2}{*}{$\mathrm{HR}(95 \% \mathrm{Cl})$} & \multirow[t]{2}{*}{ P-value } & \multirow[t]{2}{*}{ Model } & \multicolumn{2}{|c|}{ Heterogeneity } \\
\hline & & & & & & $12(\%)$ & $\mathrm{Ph}$ \\
\hline Overall survival & 9 & 656 & $1.83[1.56,2.14]$ & $₫ 0.00001$ & Fixed & $0 \%$ & 0.52 \\
\hline \multicolumn{8}{|l|}{ Cancer type } \\
\hline Digestive system tumors & 3 & 271 & $1.68[1.36,2.09]$ & $\llbracket 0.00001$ & Fixed & $7 \%$ & 0.34 \\
\hline other tumors & 6 & 385 & $1.97[1.52,2.56]$ & $\varangle 0.00001$ & Fixed & $0 \%$ & 0.61 \\
\hline \multicolumn{8}{|l|}{ Survival analysis } \\
\hline Survival curve & 3 & 275 & $1.63[1.28,2.07]$ & $\llbracket 0.0001$ & Fixed & $28 \%$ & 0.25 \\
\hline Multivariate analysis & 6 & 381 & $1.96[1.56,2.47]$ & $\llbracket 0.00001$ & Fixed & $0 \%$ & 0.75 \\
\hline \multicolumn{8}{|l|}{ Cut-off value } \\
\hline Median & 7 & 461 & $1.84[1.51,2.24]$ & $\varangle 0.00001$ & Fixed & $0 \%$ & 0.44 \\
\hline Others & 2 & 195 & $1.68[1.23,2.29]$ & 0.001 & Fixed & $0 \%$ & 0.48 \\
\hline
\end{tabular}

\subsection{Analysis of clinical parameters}

A total of ten studies that included in meta-analysis reported with related clinical parameters, including age, gender, differentiation grade, tumor size, clinical stage, distant metastasis (DM) and lymph node metastasis (LNM) (Table 3). High expression of MCM3P-AS1 was not largely related to age $(\mathrm{OR}=0.79,95 \% \mathrm{Cl}: 0.56-1.12, \mathrm{P}=0.19)(\mathrm{Fig} .4 \mathrm{a})$, gender $(\mathrm{OR}=0.90,95 \% \mathrm{Cl}: 0.62-1.30, \mathrm{P}=0.58)(\mathrm{Fig} .4 \mathrm{~b})$, and $\mathrm{DM}$ $(\mathrm{OR}=1.77,95 \% \mathrm{Cl}: 0.91-3.45, \mathrm{P}=0.09)$ (Fig. 5b). Additionally, there was distinct relationship between high level of MCM3P-AS1 and poor differentiation ( $O R=1.76,95 \% \mathrm{Cl}: 1.12-2.75, \mathrm{P}=0.01)$ (Fig. 4c), larger tumor size ( $\mathrm{OR}=2.70,95 \% \mathrm{Cl}: 1.13-6.46, \mathrm{P}=0.03)$ (Fig. 4d), advanced clinical stage $(\mathrm{OR}=2.52,95 \% \mathrm{Cl}: 1.32-4.81, \mathrm{P}=0.005)$ (Fig. $5 \mathrm{a})$, and earlier $\mathrm{LNM}(\mathrm{OR}=2.85,95 \% \mathrm{Cl}: 1.16-7.00, \mathrm{P}=0.02)(\mathrm{Fig} .5 \mathrm{C})$.

Table 3

Meta-analysis of the association between MCM3AP-AS1 expression and clinicopathological parameters.

\begin{tabular}{|c|c|c|c|c|c|c|c|}
\hline \multirow[t]{2}{*}{ Clinicopathological parameters } & \multirow{2}{*}{$\begin{array}{l}\text { Studies } \\
\text { (n) }\end{array}$} & \multirow{2}{*}{$\begin{array}{l}\text { Number of } \\
\text { patients }\end{array}$} & \multirow{2}{*}{$\begin{array}{l}\text { Odds ratio }(95 \% \\
\mathrm{Cl})\end{array}$} & \multirow{2}{*}{$\begin{array}{l}\mathrm{P}- \\
\text { value }\end{array}$} & \multirow[t]{2}{*}{ Model } & \multicolumn{2}{|c|}{ Heterogeneity } \\
\hline & & & & & & $\begin{array}{l}I^{2} \\
(\%)\end{array}$ & $\mathrm{P}_{\mathrm{h}}$ \\
\hline Age (old vs young) & 9 & 557 & $0.79[0.56,1.12]$ & 0.19 & Fixed & $0 \%$ & 0.93 \\
\hline Gender (male vs female) & 8 & 497 & $0.90[0.62,1.30]$ & 0.58 & Fixed & $0 \%$ & 0.63 \\
\hline $\begin{array}{l}\text { Differentiation (poor vs } \\
\text { good+moderate) }\end{array}$ & 5 & 322 & $1.76[1.12,2.75]$ & 0.01 & Fixed & $18 \%$ & 0.30 \\
\hline Tumor size (large vs small) & 6 & 401 & $2.70[1.13,6.46]$ & 0.03 & Random & $76 \%$ & 0.0009 \\
\hline Clinical stage (III+IV vs I+II) & 10 & 621 & $2.52[1.32,4.81]$ & 0.005 & Random & $69 \%$ & 0.0007 \\
\hline DM (yes vs no) & 2 & 146 & $1.77[0.91,3.45]$ & 0.09 & Fixed & $0 \%$ & 0.98 \\
\hline LNM (yes vs no) & 4 & 235 & $2.85[1.16,7.00]$ & 0.02 & Random & $56 \%$ & 0.08 \\
\hline
\end{tabular}

Cl: confidence interval; DM distant metastasis, LNM lymph node metastasis. 


\subsection{Publication bias}

A funnel plot among 9 studies included in this meta-analysis was presented (Fig.6). The Begg's test (Pr continuity corrected $>|z|=0.005$ ) (Fig. 6a) were used to detecting publication bias. The funnel plot revealed that our finding had publication bias. Perhaps, since some negative results were not published, the forest map with publication bias was filled. As the filled funnel plot showed (Fig. 6b), the results of this meta-analysis were reliable $(\mathrm{HR}=1.66,95 \% \mathrm{Cl}: 1.44-1.91, \mathrm{P}<0.001)$.

\section{Discussion}

Since the advent of the genomic era in 2000 , scientists have made significant progress in understanding the prevalence, abundance, biosynthesis and potential functions of IncRNAs in different organisms and types of cells. In particular, the studies of IncRNAs have been became a new star again after the structure and function of LnCRNA H19 and XIST were elucidated. In latest, numerous studies have shown that IncRNAs played important roles in regulating chromatin dynamics, gene expression, growth, differentiation, and development[22, 23]. In addition, IncRNAs were associated with a variety of human diseases, including inflammatory diseases[24], diabetes[25], various cancers[12, 26], neurological[27] and cardiovascular diseases[28]. LncRNAs were abundantly expressed and widely associated with a variety of cancers, and the aberrant expressions were closely linked to tumorigenesis, metastasis, and tumor stage in the course of tumor biology[29, 30]. The above ideas suggested that IncRNAs could be used as a novel potential biomarker and therapeutic target to accurately assist in diagnosis and assessment of prognosis.

LncRNA MCM3AP-AS1 was a newly identified IncRNA. It has been reported that the expression of MCM3AP-AS1 was increased in many different types of tumors and involved in tumorigenesis, progression, and metastasis[17, 31]. Wang et al.[17] found that MCM3AP-AS1 functioned as an oncogenic IncRNA by acting as a competing endogenous RNA to sponge miR-194-5p and subsequently promoted forkhead box A1 (FOXA1) expression. Meanwhile, another study had indicated that upregulation of MCM3AP-AS1 promoted the progression and the aggressiveness of prostate cancer. Mechanically, MCM3AP-AS1 enhanced neuropeptide Y1 receptor (NPY1R) methylation by recruiting DNA methyltransferase (DNMT1/DNMT3) to the NPY1R promoter, thus downregulating NPY1R expression and then activating the mitogenactivated protein kinase (MAPK) pathway, which promoted prostate cancer progression and invasiveness[32]. Subsequently, a study has pointed out that IncRNA MCM3AP-AS1 regulated epidermal growth factor receptor and autophagy signal pathway to promote hepatocellular carcinoma metastasis by interacting with miR-455[33]. Sun et al.[34] found that MCM3AP-AS1 enhanced cisplatin resistance by interacting with miR-138 to upregulate forkhead box C1 (FOXC1) expression. To sum up, all these studies indicated that IncRNA MCM3AP-AS1 was a promising potential biomarker.

In this meta-analysis, compared with patients with lower IncRNA expression, we found that MCM3AP-AS1 upregulation had worse OS (HR = $1.83,95 \% \mathrm{Cl}: 1.56-2.14, \mathrm{P}<0.00001)$. The result showed that IncRNA MCM3AP-AS1 might be an unfavorable prognostic factor for cancer patients. A subgroup analysis stratified by cancer type, survival analysis type and expression intercept showed similar results. In addition, the relationship between MCM3AP-AS1 expression with clinical parameters was evaluated for 10 studies including 621 patients. The pooled results indicated that increased MCM3AP-AS1 expression was meaningfully associated with worse differentiation(OR $=1.76,95 \% \mathrm{Cl}$ : $1.12-2.75, \mathrm{P}=0.01)$, larger tumor size $(\mathrm{OR}=2.70,95 \% \mathrm{Cl}: 1.13-6.46, \mathrm{P}=0.03)$, advanced clinical stage $(\mathrm{OR}=2.52,95 \% \mathrm{Cl}: 1.32-4.81, \mathrm{P}=$ 0.005 ) and lymph node metastasis $(\mathrm{OR}=2.85,95 \% \mathrm{Cl}: 1.16-7.00, \mathrm{P}=0.02)$. we inferred that MCM3AP-AS1 might be significantly associated with malignant tumors progression and metastasis.

In summary, high expression of IncRNA MCM3AP-AS1 was an unfavorable prognostic factor for most patients with malignant tumors and might be used as a promising biomarker. This study provided a new basis for the diagnosis and treatment of patients with advanced tumors and allowed a more accurate assessment of the prognosis of malignancies. The highlights of the current study were as follows: First, this was the first study that comprehensively analyzed the relationship between the expression of IncRNA MCM3AP-AS1 and the prognostic outcome of human cancer based on our document retrieval. Second, this study strictly followed the recommendations of the PRISMA statement, so the results obtained were plausible. In addition, the results were relatively accurate because a fixed-effects model was used in most of our analyses.

Despite the rigorous search strategy and inclusion exclusion criteria, this study also has some deficiencies and limitations. Firstly, statistical heterogeneity was found in the current studies, possibly originating from different types of cancer. Then, a portion of the original studies did not directly provide the value of HR, which were obtained indirectly by extracting from survival curves. These values might not be fully accurate. Thirdly, the total sample size was relatively small, which might reduce the stringency of the conclusions. Fourthly, there was no clear cut-off value of IncRNA MCM3AP-AS1 expression. Finally, all patients included in the study were from China, which might lead to geographical bias. 
Taken together, IncRNA MCM3AP-AS1 was highly associated with poor prognosis. Also, overexpression of MCM3AP-AS1 was largely related to worse differentiation, larger tumor size, advanced clinical stage and lymph node metastasis. However, the conclusion still required further larger-scale, higher-quality studies to validate these findings.

\section{Abbreviations}

MCM3AP-AS1: Minichromosome maintenance complex component 3 associated protein-antisense RNA 1; HR: hazard ratio; Cl: confidence interval; OS: overall survival; LncRNA: Long non-coding RNA; LNM: lymph node metastasis; DM: distant metastasis; NOS: Newcastle-Ottawa scale; OR: odds ratio; qRT-PCR: quantitative reverse transcription polymerase chain reaction; CP: clinicopathological parameters; FC: fold change; MA: multivariate analysis; SC: survival curve

\section{Declarations Contributions}

QL and NY designed the study; WC and LJ collected the publications and conducted the meta-analysis; WWH helped with the meta-analysis and the sensitive analysis; QL drafted the manuscript; NY revised the manuscript.

\section{Ethics approval and consent to participate}

Not applicable.

\section{Availability of data and materials}

The datasets used and/or analyzed during the current study are available from the corresponding author on reasonable request.

\section{Consent for publication}

All authors have read and approved the manuscript.

\section{Competing interests}

The authors declare that there is no competing interest.

\section{Funding}

This work was supported by a the National Natural Science Foundation of China (82060527); this work also received funding from the First Hospital of Lanzhou University (Idyyyn2019-02).

\section{Acknowledgements}

Not applicable.

\section{References}

1. Zaorsky NG, Zhang Y, Tuanquin L, Bluethmann SM, Park HS, Chinchilli VM: Suicide among cancer patients. Nature Communications2019, 10.

2. Sung H, Ferlay J, Siegel RL, Laversanne M, Soerjomataram I, Jemal A, Bray F: Global Cancer Statistics 2020: GLOBOCAN Estimates of Incidence and Mortality Worldwide for 36 Cancers in 185 Countries. CA Cancer J Clin2021, 71(3):209-249.

3. Wu L, Qu X: Cancer biomarker detection: recent achievements and challenges. Chem Soc Rev2015, 44(10):2963-2997.

4. Kung JT, Colognori D, Lee JT: Long noncoding RNAs: past, present, and future. Genetics2013, 193(3):651-669. 
5. Jandura A, Krause HM: The New RNA World: Growing Evidence for Long Noncoding RNA Functionality. Trends in Genetics2017, 33(10):665-676.

6. Lee H, Zhang Z, Krause HM: Long Noncoding RNAs and Repetitive Elements: Junk or Intimate Evolutionary Partners? Trends Genet2019, 35(12):892-902.

7. Ponjavic J, Ponting CP, Lunter G: Functionality or transcriptional noise? Evidence for selection within long noncoding RNAs. Genome Res2007, 17(5):556-565.

8. Brannan Cl, Dees EC, Ingram RS, Tilghman SM: The Product of the H19 Gene May Function as an Rna. Molecular and Cellular Biology1990, 10(1):28-36.

9. Brockdorff N, Ashworth A, Kay GF, Mccabe VM, Norris DP, Cooper PJ, Swift S, Rastan S: The Product of the Mouse Xist Gene Is a 15 Kb Inactive X-Specific Transcript Containing No Conserved Orf and Located in the Nucleus. Cel/1992, 71(3):515-526.

10. Clemson CM, McNeil JA, Willard HF, Lawrence JB: XIST RNA paints the inactive X chromosome at interphase: Evidence for a novel RNA involved in nuclear chromosome structure. Journal of Cell Biology1996, 132(3):259-275.

11. Lin A, Li C, Xing Z, Hu Q, Liang K, Han L, Wang C, Hawke DH, Wang S, Zhang Y et al: The LINK-A IncRNA activates normoxic HIF1alpha signalling in triple-negative breast cancer. Nat Cell Bio/2016, 18(2):213-224.

12. Gutschner T, Diederichs S: The hallmarks of cancer: a long non-coding RNA point of view. RNA Bio/2012, 9(6):703-719.

13. Prensner JR, lyer MK, Balbin OA, Dhanasekaran SM, Cao Q, Brenner JC, Laxman B, Asangani IA, Grasso CS, Kominsky HD et al: Transcriptome sequencing across a prostate cancer cohort identifies PCAT-1, an unannotated lincRNA implicated in disease progression. Nat Biotechno/2011, 29(8):742-U134.

14. Ji P, Diederichs S, Wang W, Boing S, Metzger R, Schneider PM, Tidow N, Brandt B, Buerger H, Bulk Eet al: MALAT-1, a novel noncoding RNA, and thymosin beta4 predict metastasis and survival in early-stage non-small cell lung cancer. Oncogene2003, $22(39): 8031-8041$.

15. Takei Y, Tsujimoto G: Identification of a novel MCM3-associated protein that facilitates MCM3 nuclear localization. Journal of Biological Chemistry1998, 273(35):22177-22180.

16. Takei Y, Swietlik M, Tanoue A, Tsujimoto G, Kouzarides T, Laskey R: MCM3AP, a novel acetyltransferase that acetylates replication protein MCM3. Embo Reports2001, 2(2):119-123.

17. Wang Y, Yang L, Chen T, Liu X, Guo Y, Zhu Q, Tong X, Yang W, Xu Q, Huang Det al: A novel IncRNA MCM3AP-AS1 promotes the growth of hepatocellular carcinoma by targeting miR-194-5p/FOXA1 axis. Mol Cancer2019, 18(1):28.

18. Jia ZH, Li WS, Bian P, Liu H, Pan D, Dou ZL: LncRNA MCM3AP-AS1 Promotes Cell Proliferation and Invasion Through Regulating miR543-3p/SLC39A10/PTEN Axis in Prostate Cancer. Oncotargets and Therapy2020, 13:9365-9376.

19. Shen DJ, Li JQ, Tao KY, Jiang YH: Long non-coding RNA MCM3AP antisense RNA 1 promotes non-small cell lung cancer progression through targeting microRNA-195-5p. Bioengineered2021, 12(1):3525-3538.

20. Ma XD, Luo J, Zhang Y, Sun DL, Lin YY: LncRNA MCM3AP-AS1 Upregulates CDK4 by Sponging miR-545 to Suppress G1 Arrest in Colorectal Cancer. Cancer Management and Research2020, 12:8117-8124.

21. Dai W, Zeng W, Lee D: IncRNA MCM3AP-AS1 inhibits the progression of colorectal cancer via the miR-19a-3p/FOXF2 axis. The journal of gene medicine2021, 23(3):e3306.

22. Jandura A, Krause HM: The New RNA World: Growing Evidence for Long Noncoding RNA Functionality. Trends Genet2017, 33(10):665676.

23. Chen LL: Linking Long Noncoding RNA Localization and Function. Trends Biochem Sci2016, 41(9):761-772.

24. Liao K, Xu J, Yang W, You X, Zhong Q, Wang X: The research progress of LncRNA involved in the regulation of inflammatory diseases. Mol Immuno/2018, 101:182-188.

25. Pullen TJ, Rutter GA: Roles of IncRNAs in pancreatic beta cell identity and diabetes susceptibility. Frontiers in genetics2014, 5:193.

26. Bhan A, Soleimani M, Mandal SS: Long Noncoding RNA and Cancer: A New Paradigm. Cancer Research2017, 77(15):3965-3981.

27. Cortini F, Roma F, Villa C: Emerging roles of long non-coding RNAs in the pathogenesis of Alzheimer's disease. Ageing Res ReV2019, 50:19-26.

28. Salamon I, Saccani Jotti G, Condorelli G: The long noncoding RNA landscape in cardiovascular disease: a brief update. Curr Opin Cardio/2018, 33(3):282-289.

29. Bartonicek N, Maag JL, Dinger ME: Long noncoding RNAs in cancer: mechanisms of action and technological advancements. Mol Cancer2016, 15(1):43.

30. Vitiello M, Tuccoli A, Poliseno L: Long non-coding RNAs in cancer: implications for personalized therapy. Cellular oncology (Dordrecht)2015, 38(1):17-28. 
31. Chen Q, Xu H, Zhu J, Feng K, Hu C: LncRNA MCM3AP-AS1 promotes breast cancer progression via modulating miR-28-5p/CENPF axis. Biomedicine \& pharmacotherapy = Biomedecine \& pharmacotherapie2020, 128:110289.

32. Li X, Lv J, Liu S: MCM3AP-AS1 KD Inhibits Proliferation, Invasion, and Migration of PCa Cells via DNMT1/DNMT3 (ABB) MethylationMediated Upregulation of NPY1R. Molecular therapy Nucleic acids2020, 20:265-278.

33. Zhang H, Luo C, Zhang G: LncRNA MCM3AP-AS1 Regulates Epidermal Growth Factor Receptor and Autophagy to Promote Hepatocellular Carcinoma Metastasis by Interacting with miR-455. DNA Cell Bio/2019, 38(8):857-864.

34. Sun H, Wu P, Zhang B, Wu X, Chen W: MCM3AP-AS1 promotes cisplatin resistance in gastric cancer cells via the miR-138/F0XC1 axis. Oncol Lett2021, 21(3):211.

\section{Figures}

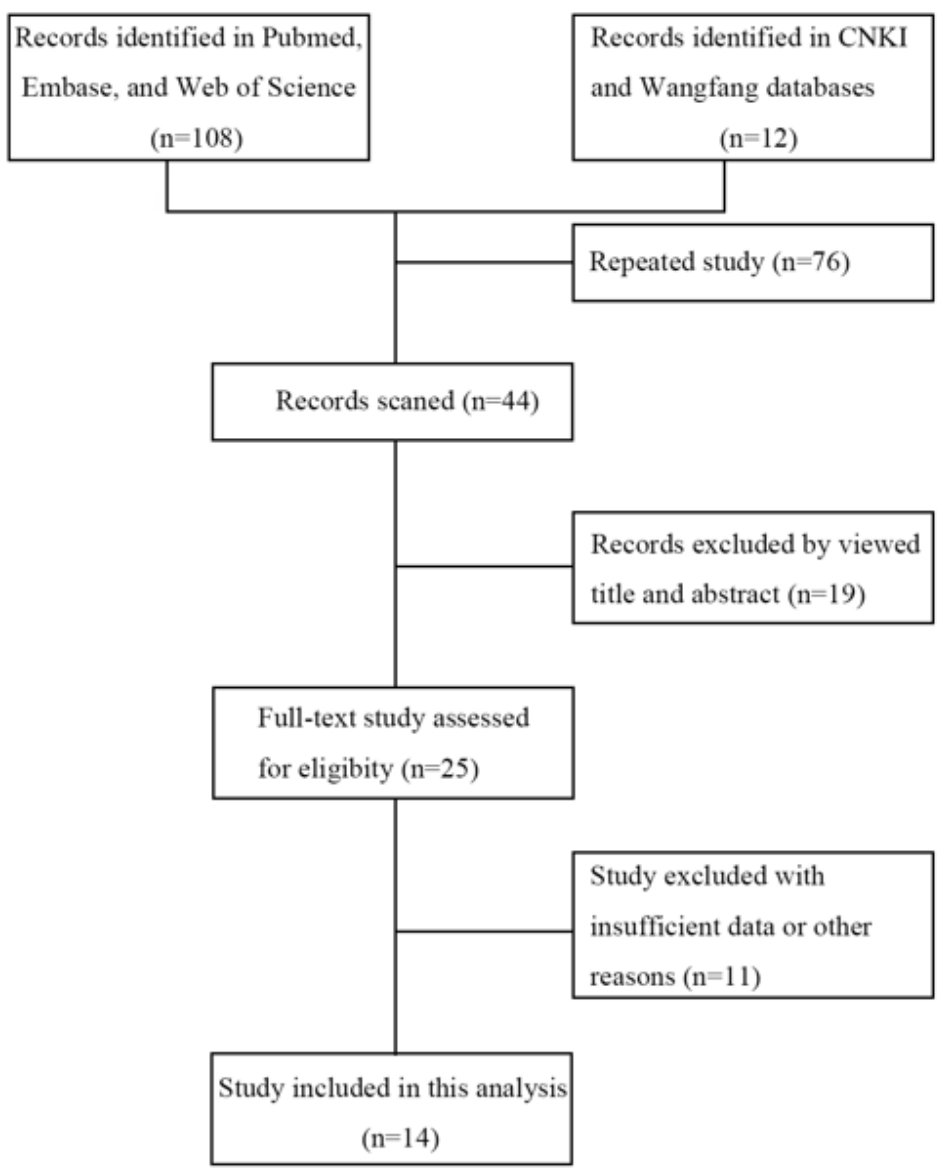

Figure 1

Flow diagram for obtaining the relevant studies. 


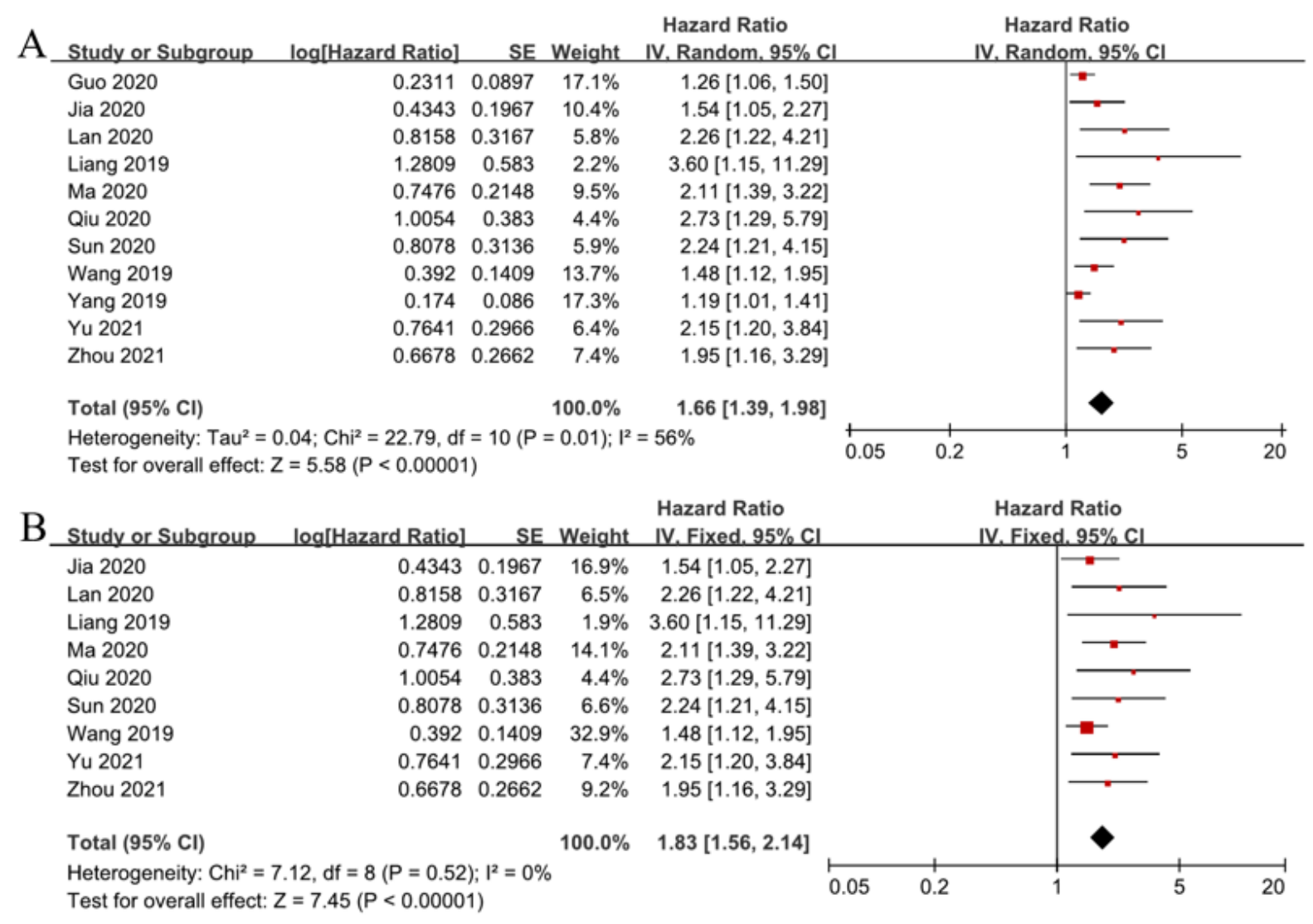

\section{Figure 2}

Relationship between high expression of IncMCM3AP-AS1 and OS with different solid tumors. (a) Articles from heterogeneous sources not excluded; (b) After the heterogeneous articles were eliminated.

Meta-analysis random-effects estimates (exponential form)

Study ommited

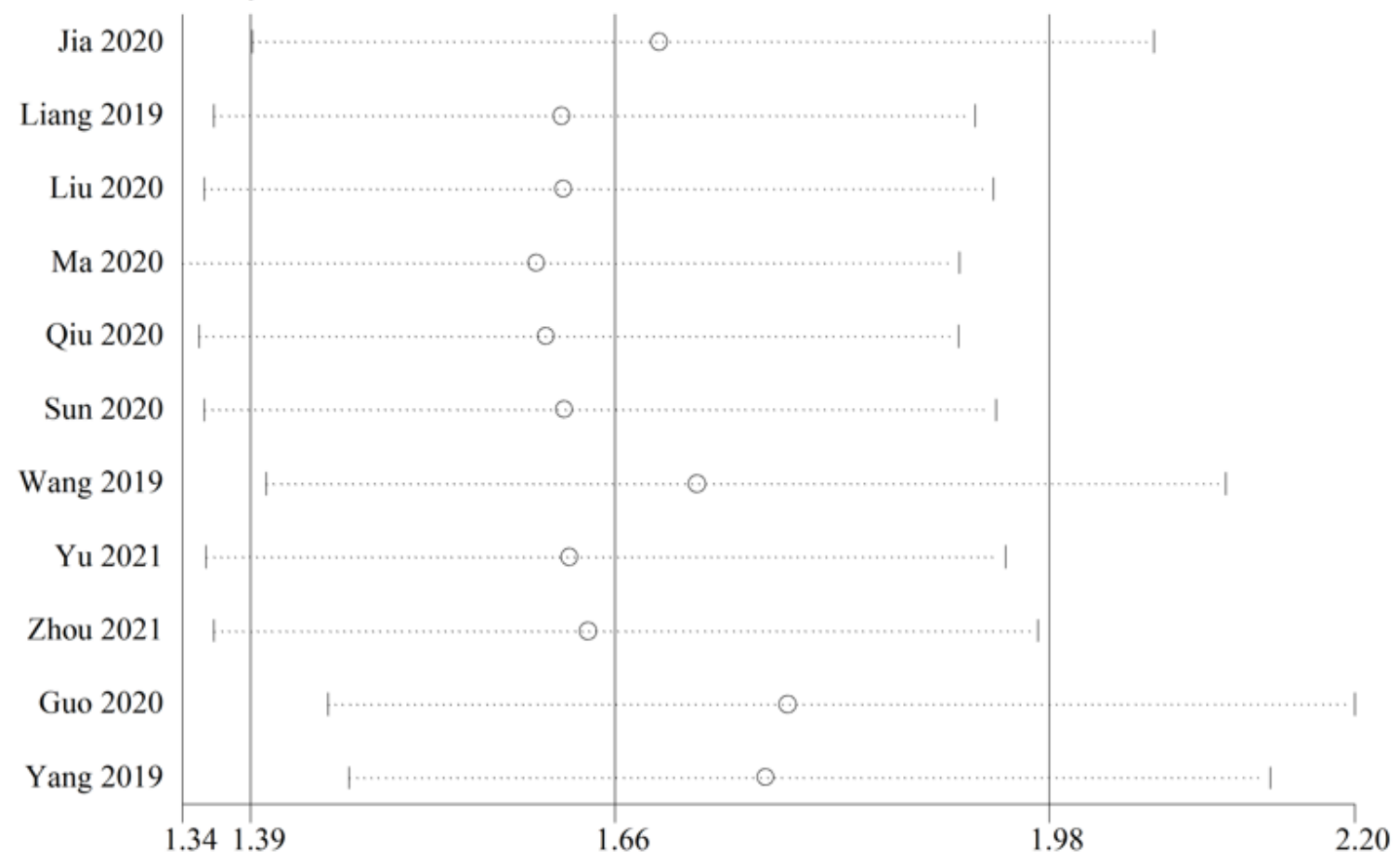




\section{Figure 3}

The sensitivity analysis of eleven studies for the meta-analysis of OS.

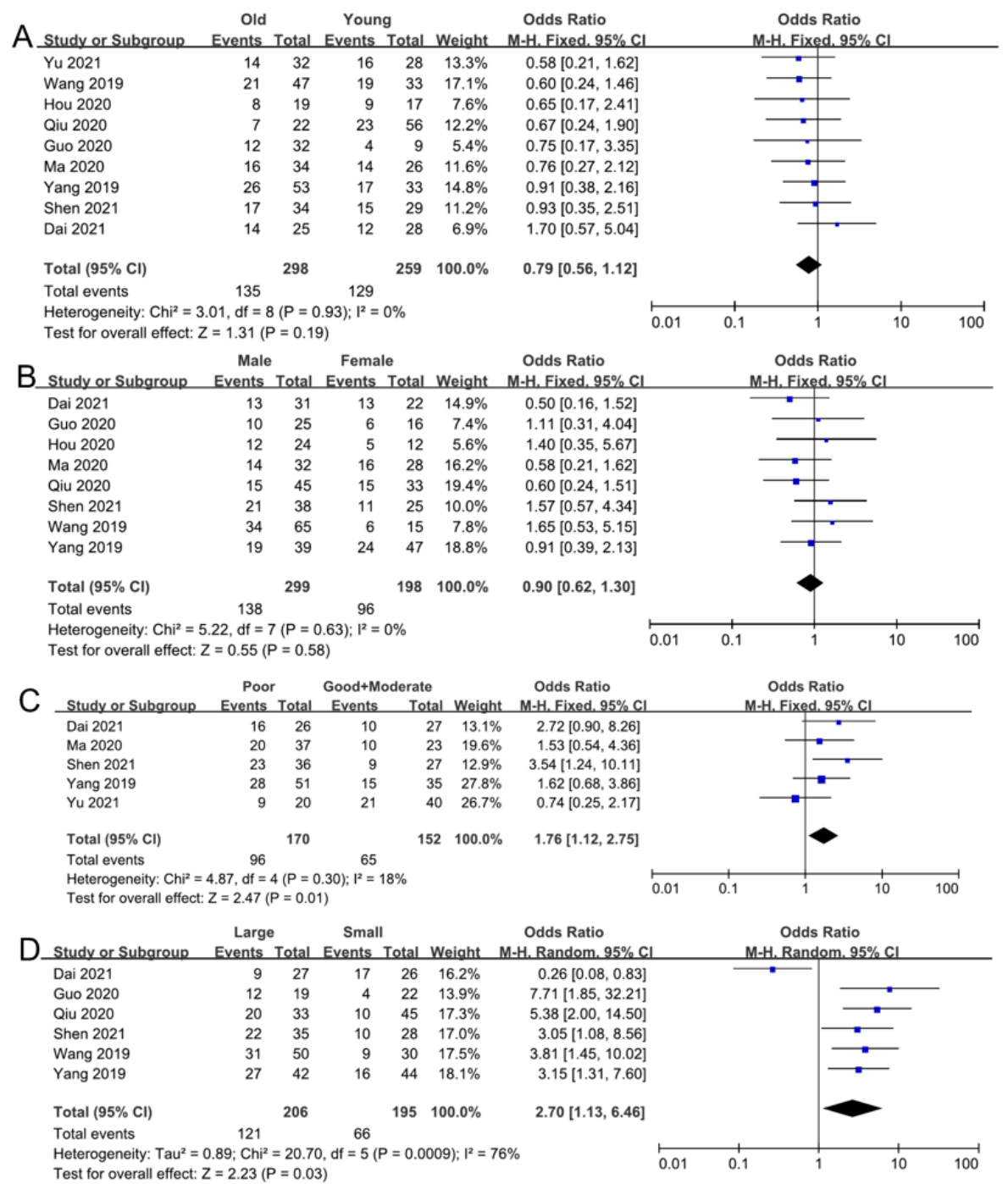

\section{Figure 4}

Forest plots of the association between MCM3AP-AS1 expression and various clinical parameters. (a) Age; (b) Gender; (c) differentiation grade; (d) tumor size. 


\begin{tabular}{|c|c|c|c|c|c|c|c|}
\hline Study or Subgroup & $\begin{array}{l}\text { III+IV } \\
\text { Events }\end{array}$ & Total & $\begin{array}{r}\text { I+II } \\
\text { Events }\end{array}$ & Total & Weight & $\begin{array}{c}\text { Odds Ratio } \\
\mathrm{M}-\mathrm{H} \text {. Random, } 95 \% \mathrm{Cl}\end{array}$ & $\begin{array}{c}\text { Odds Ratio } \\
\mathrm{M}-\mathrm{H}, \text { Random, } 95 \% \mathrm{Cl}\end{array}$ \\
\hline Dai 2021 & 12 & 33 & 14 & 20 & $9.9 \%$ & $0.24[0.07,0.81]$ & \\
\hline Guo 2020 & 12 & 22 & 4 & 19 & $8.8 \%$ & $4.50[1.13,17.99]$ & \\
\hline Hou 2020 & 13 & 20 & 4 & 16 & $8.4 \%$ & $5.57[1.30,23.93]$ & \\
\hline Jia 2020 & 25 & 40 & 7 & 24 & $10.4 \%$ & $4.05[1.36,12.02]$ & \\
\hline Ma 2020 & 20 & 38 & 10 & 22 & $10.6 \%$ & $1.33[0.46,3.82]$ & \\
\hline Qiu 2020 & 27 & 50 & 3 & 28 & $9.2 \%$ & $9.78[2.61,36.63]$ & \\
\hline Shen 2021 & 24 & 38 & 8 & 25 & $10.5 \%$ & $3.64[1.25,10.60]$ & \\
\hline Wang 2019 & 15 & 19 & 25 & 61 & $9.7 \%$ & $5.40[1.60,18.20]$ & \\
\hline Yang 2019 & 23 & 36 & 20 & 50 & $11.6 \%$ & $2.65[1.10,6.43]$ & \\
\hline Yu 2021 & 15 & 31 & 15 & 29 & $10.9 \%$ & $0.88[0.32,2.41]$ & \\
\hline Total $(95 \% \mathrm{Cl})$ & & 327 & & 294 & $100.0 \%$ & $2.52[1.32,4.81]$ & \\
\hline Tatal anonta & 100 & & $11 n$ & & & & \\
\hline
\end{tabular}

\section{Figure 5}

Forest plots of the association between MCM3AP-AS1 expression and various clinical parameters. (a) clinical stage; (b) DM; (c) LNM.
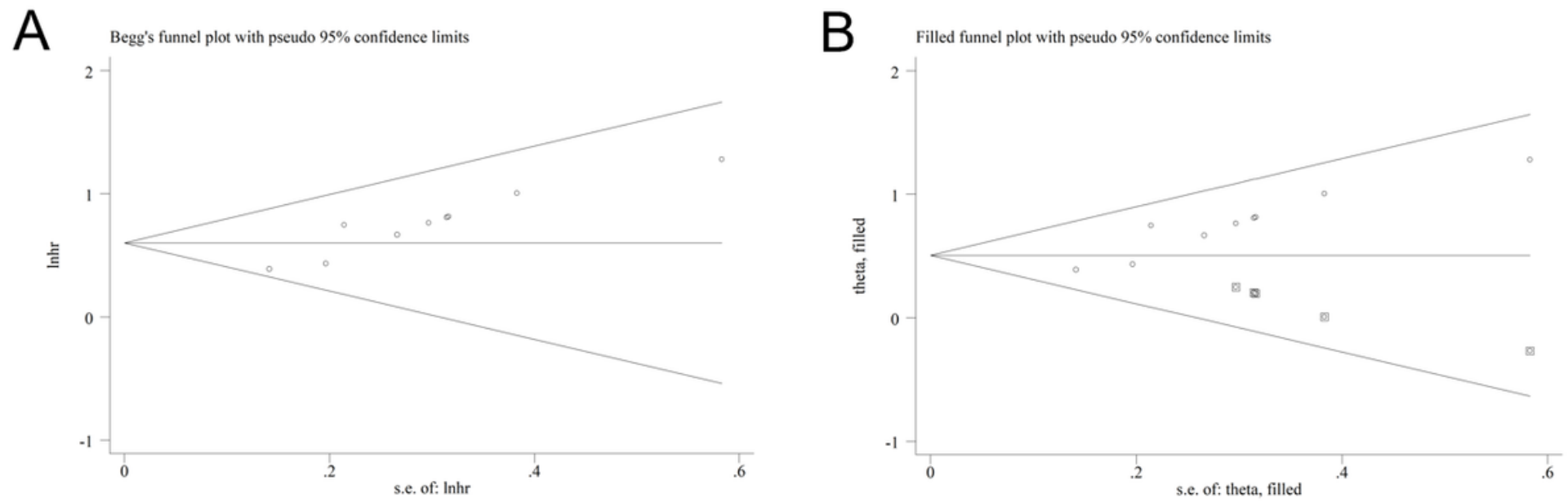

Figure 6 
Publication bias assessment. (a) Begg funnel plot; (b) Filled funnel plot.

Page 14/ 14 